\title{
Pre-Decisional Sodium Bearing Waste Technology Development Roadmap FY-01 Update
}

Gary McDannel

September 2001

Idaho National Engineering and Environmental Laboratory Bechtel BWXT Idaho, LLC 


\title{
Pre-Decisional Sodium Bearing Waste Technology Development Roadmap FY-01 Update
}

\author{
Gary McDannel
}

September 2001

Idaho National Engineering and Environmental Laboratory Idaho Falls, Idaho 83415

Prepared for the U.S. Department of Energy Under DOE Idaho Operations Office Contract DE-AC07-99ID13727 


\begin{abstract}
This report provides an update to the Sodium Bearing Waste (SBW) Technology Development Roadmap generated a year ago. It outlines progress made to date and near-term plans for the technology development work necessary to support processing SBW. In addition, it serves as a transition document to the Risk Management Plan (RMP) required by the Project per DOE Order 413.3, "Program and Project Management for the Acquisition of Capital Assets." Technical uncertainties have been identified as design basis elements (DBEs) and captured in a technical baseline database. As the risks are discovered, assessed, and mitigated, the status of the DBEs in the database will be updated and tracked to closure.
\end{abstract}




\section{SUMMARY}

Dispositioning sodium-bearing waste (SBW) at the Idaho National Engineering and Environmental Laboratory (INEEL) remains a top priority for the State of Idaho and the Laboratory. This waste exists in liquid form and is contained in underground stainless steel tanks that do not comply with the Resource Conservation and Recovery Act (RCRA). Removing this waste from these tanks and treating it by the end of 2012 remains a commitment in the Settlement Agreement between the State of Idaho and the Department of Energy.

The previous version of the roadmap outlined key technology development activities necessary to support treatment of SBW. These are logically grouped into the following areas: (1) characterization of SBW and glass, (2) melter material balance and operation, (3) off-gas characterization and treatment, and (4) secondary waste generation and disposal.

Ideally, each of these areas would be addressed sequentially, since a change in SBW composition, for example, would alter melter and off-gas performance. However, due to the expedited schedule for treating SBW, the technology development efforts are being conducted in parallel. Development efforts in fiscal year 2001 concentrated on the first three areas, with the following major outcomes:

- Characterization of SBW in one of the four planned 300, 000-gallon storage tanks (WM-180) was completed.

- Compositional variation studies on 64 glass formulations were conducted to establish preliminary waste form qualification boundary conditions for feed mixtures.

- $\quad$ Pilot and bench-scale testing was completed during three separate test runs. Although physical properties of the glass produced have been within acceptable limits, a significant discovery resulted with formation of a sulfate layer in the melt. This anomaly was not predicted by the crucible tests being used for waste formulation development indicating a potential scale-up issue. Waste loading was reduced to $20 \%$ (for WM-180 SBW) and frit formulations adjusted in an attempt to compensate. Results are pending, but appear favorable.

- Off-gas speciation was evaluated from the pilot runs. Data from these tests has been collected but final analysis has not been completed. Cesium volatility appears higher than expected. In laboratory studies, removal efficiencies for both elemental and oxidized forms of mercury using granular activated carbon have exceeded $99 \%$. However, the speciation of mercury throughout the off-gas treatment process remains largely undefined. 
- Cold-crucible induction melter technology being utilized in France and Russia was studied with favorable preliminary indications.

Technology development activities funded by EM-40 and -50 for the next three years include (1) continued characterization of the remaining SBW tanks, (2) continued compositional variation studies for waste form qualification, (3) melt-rate studies with bench and pilot scale melters, (4) evaluation of cold crucible induction melter technology, (5) process modeling, and (6) improved waste loading. Funding levels are projected to increase, but lower-thananticipated funding in FY-01 and FY-02, combined with the discoveries, contributes to increased uncertainty in finalizing the process flowsheet.

As the Project progresses through each critical decision (CD) point outlined by DOE Order 413.3, "Program and Project Management for the Acquisition of Capital Assets," it will be imperative that the technical issues are sufficiently addressed. The first CD point (CD-0, Approve Mission Need) is scheduled to occur in the $1^{\text {st }}$ quarter of FY-03. Based on uncertainties to date, continued focus is required to ensure that these risks are identified and mitigated before obtaining CD-0 approval.

In addition to the technology development activities completed to date, the pre-conceptual Project related activities included development of a risk management plan. In accordance with the requirements of DOE Order 413.3, risk assessment reports identify the technological risks and uncertainties, as well as other programmatic risks, that must be addressed to ensure successful Project completion. Similarly, a primary function of the SBW Technology Development Roadmap is identification of technical uncertainties and assurance that these uncertainties are properly managed (scheduled, prioritized, mitigated, etc.). Therefore, primarily to avoid redundancy, it was deemed appropriate to transition the database of technical uncertainties in the roadmap over to the risk management plan. This approach will improve integration of the technology development activities with the needs and priorities of the construction Project planned for dispositioning SBW. It is also consistent with the planned deployment of technologies in support of plant design, construction, and operation.

In summary, this Roadmap update is limited in scope to statusing activities outlined in last year's Roadmap, identifying pending high-risk items, and establishing a transition to the risk management plan. 


\section{CONTENTS}

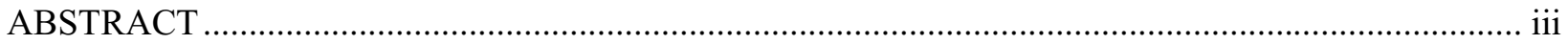

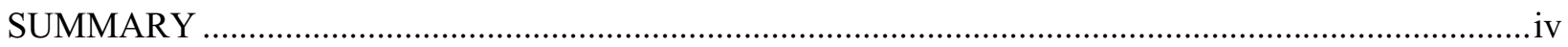

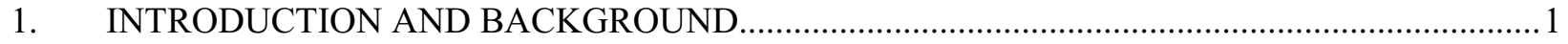

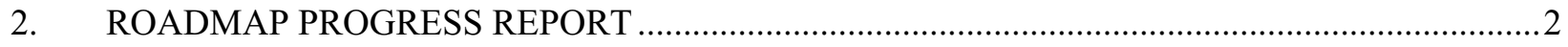

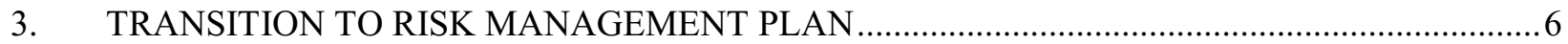

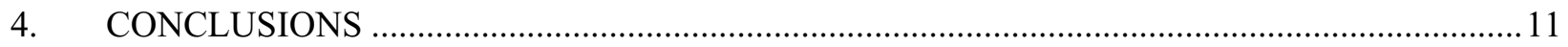

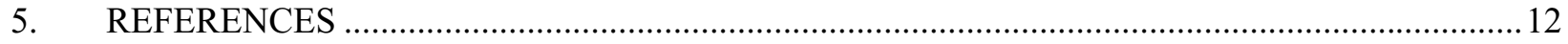

Appendix A-Bechtel BWXT Idaho, LLC, PBS-102 Idaho Waste Vitrification Technology Development Work Package Schedules

Appendix B-Idaho Waste Vitrification Facilities Project Schedule

\section{FIGURES}

Figure 1. SBW Technology Development Projected Funding Profile..................................................... 5

Figure 2. Roadmapping Process and Products Diagram (as provided in the EM-50 Draft Guidance)........ 7

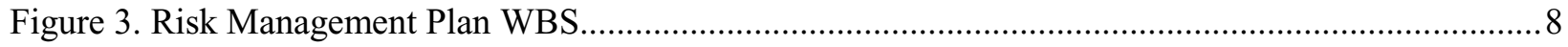

Figure 4. Risk Management Plan Documents Relative to Project Phase. ................................................. 9

Figure 5. Risk Management Process Relative to Project Phase. .............................................................. 10

\section{TABLES}

Table 1. Listing of High Priority Design Basis Elements, Status and Plans. 


\section{Pre-Decisional Sodium Bearing Waste Technology Development Roadmap FY-01 Update}

\section{INTRODUCTION AND BACKGROUND}

The INEEL has approximately one million gallons of sodium bearing waste (SBW) requiring treatment. Historically, SBW has been blended with high-level raffinate from nuclear fuel reprocessing and has been calcined. More recently, a revised high-temperature flowsheet was developed, and SBW was successfully calcined without blending. However, for a number of varied reasons, the Department of Energy (DOE) is re-evaluating this treatment methodology and has drafted an Environmental Impact Statement that has identified alternatives for treatment of SBW. One such alternative is direct vitrification. At the direction of DOE, the technology development efforts over the past year have concentrated on this technology.

To guide technology development for treatment of SBW, roadmapping was employed and a report issued a year ago (Olson, Murphy, and Perry 2000). The Roadmap was used during the last year to guide the technology development activities. Section 2.0 discusses the progress made to date and additional uncertainties identified.

As required by DOE Order 413.3, "Program and Project Management for the Acquisition of Capital Assets," the Project has developed a risk management plan (RMP). The RMP serves essentially the same function as the roadmap by identifying the technological risks and management thereof. Consequently, this update to the roadmap is abbreviated and serves primarily as a transition document to the RMP.

DOE Order 413.3 outlines critical decision (CD) points for large capital projects. Achieving approval at each CD point is necessary for the project to remain viable. The "Office of Environmental Management Project Definition Rating Index Manual" (EM-PDRI) identifies those items considered important for each CD point and scores each project according to established criteria. Of particular importance to the SBW Vitrification Project is the upcoming approval at CD-0 (Approve Mission Need). The technical criteria, in order of priority, are alternative analysis, systems engineering, technology needs identified and demonstrated, functional requirements, design basis, and waste acceptance. The rating index requires a relative high maturity level and progression in the area of technologies being applied to the project. 


\section{ROADMAP PROGRESS REPORT}

Last year's Roadmap was used as a guide to focus the technology development activities. It identified three possible paths for treating SBW: (1) direct vitrification, (2) solvent extraction, and (3) cesium ion exchange. At the beginning of FY-01, DOE directed that the technology development efforts focus on direct vitrification. Previous technology development efforts had primarily focused on cesium ion exchange with grouted waste to the Waste Isolation Pilot Plant (WIPP). This transition has forced a steep learning curve at INEEL regarding vitrification. This redirection has been supported significantly by other national and university laboratories and other DOE sites where vitrification technology is considerably advanced.

The FY-01 Roadmap identified several uncertainties (67) that have subsequently been prioritized. In addition, new uncertainties have been added based on knowledge gained (e.g. through discoveries) during the year. These uncertainties have been mapped to design basis elements (DBEs) and are contained in a technical baseline database for tracking purposes (Taylor, Barnes, and Lauerhass 2001).

The highest priority tasks, the progress made to date, and the plans for future resolution are summarized in Table 1 below. The Priority 1 items are those judged to impact process feasibility and the basic facility design and footprint. Out-year plans are contained in Detailed Work Plans (DWPs) for the next three fiscal years. The Priority 1 DBEs are grouped according to the following categories:

- $\quad$ Characterization of SBW and glass

- Melter material balance and operation

- Off-gas characterization and treatment

- $\quad$ Secondary waste generation and disposal

Table 1. Listing of High Priority Design Basis Elements, Status and Plans.

\begin{tabular}{lll}
\hline \multicolumn{1}{c}{ Design Basis Element } & \multicolumn{1}{c}{ Status - FY-01 } & \multicolumn{1}{c}{ Plans - DWP '02-'04 } \\
\hline $\begin{array}{l}\text { Total volume and } \\
\text { composite SBW feed } \\
\text { composition }\end{array}$ & $\begin{array}{l}\text { Sampled and completed analysis of WM- } \\
180-\text { one of four planned SBW tanks }\end{array}$ & $\begin{array}{l}\text { Sample remaining tanks } \\
\text { following evaporation }\end{array}$ \\
$\begin{array}{l}\text { Representativeness of cold } \\
\text { simulants in melter tests }\end{array}$ & $\begin{array}{l}\text { Glass from simulants was compared to } \\
\text { glass from hot waste (WM-180) to } \\
\text { validate simulant composition and } \\
\text { behavior. Off-gas consistency was not } \\
\text { evaluated. }\end{array}$ & $\begin{array}{l}\text { Develop cold simulants for } \\
\text { remaining tanks }\end{array}$ \\
$\begin{array}{l}\text { Preliminary Compositional Variation } \\
\text { Studies (CVS) were completed. }\end{array}$ & Continue CVS analysis \\
$\begin{array}{l}\text { locceptable glass feed } \\
\text { In SBine-129 concentration } \\
\text { in SBW feed }\end{array}$ & $\begin{array}{l}\text { I-129 is expected to be sufficiently low, } \\
\text { but if not, could cause secondary waste } \\
\text { disposal issues. Further characterization } \\
\text { of SBW tanks required. }\end{array}$ & $\begin{array}{l}\text { Analyze remaining tanks } \\
\text { for I-129 }\end{array}$ \\
& &
\end{tabular}




\begin{tabular}{|c|c|c|}
\hline Design Basis Element & Status - FY-01 & Plans - DWP ‘02-`04 \\
\hline \multicolumn{3}{|c|}{ Characterization of SBW and glass (continued) } \\
\hline $\begin{array}{l}\text { Noble metals } \\
\text { concentration in SBW feed }\end{array}$ & $\begin{array}{l}\text { WM-180 characterized. Remaining SBW } \\
\text { tanks require characterization. }\end{array}$ & $\begin{array}{l}\text { Sample remaining tanks } \\
\text { for noble metals following } \\
\text { evaporation. Evaluate } \\
\text { formulations and } \\
\text { alternative melter } \\
\text { technologies (e.g. bottom } \\
\text { drain to avoid } \\
\text { accumulation). }\end{array}$ \\
\hline Waste loading in glass & $\begin{array}{l}\text { Pilot studies generated unexpected sulfate } \\
\text { layer in melt at original waste loading. } \\
\text { Pilot scale tests at new waste loading } \\
(20 \%) \text { not yet completed. Sulfate layer } \\
\text { formation appears to be controlling factor } \\
\text { for glass. }\end{array}$ & $\begin{array}{l}\text { Evaluate alternative } \\
\text { formulations and melter } \\
\text { technologies to increase } \\
\text { waste loading }\end{array}$ \\
\hline \multicolumn{3}{|c|}{ Melter material balance and operation } \\
\hline $\begin{array}{l}\text { Speciation and partitioning } \\
\text { of sulfate in melter }\end{array}$ & $\begin{array}{l}\text { Pilot studies tested one glass formulation. } \\
\text { May affect off-gas partitioning. Results } \\
\text { being analyzed. }\end{array}$ & Conduct pilot tests \\
\hline $\begin{array}{l}\text { Partition factors for feed } \\
\text { species in melter }\end{array}$ & $\begin{array}{l}\text { One pilot study and some laboratory } \\
\text { studies completed, but final analysis } \\
\text { remains. Not all species of concern } \\
\text { evaluated (e.g. Hg). Scale-up issues } \\
\text { emerging. }\end{array}$ & $\begin{array}{l}\text { Conduct additional } \\
\text { laboratory and pilot tests. }\end{array}$ \\
\hline $\begin{array}{l}\text { Safe Handling of melter } \\
\text { feed during abnormal } \\
\text { shutdown }\end{array}$ & $\begin{array}{l}\text { None in FY-01- previous fire/explosion } \\
\text { concern raised with calcination from } \\
\text { mixing sugar (reductant) and SBW - } \\
\text { nitrated organics }\end{array}$ & $\begin{array}{l}\text { Evaluate direct reductant } \\
\text { feed to melter/alternative } \\
\text { melter technology. } \\
\text { Conduct preliminary } \\
\text { safety analysis. }\end{array}$ \\
\hline $\begin{array}{l}\text { Disposition/Handling of } \\
\text { noble metals in melter }\end{array}$ & $\begin{array}{l}\text { Calculations indicate minimal } \\
\text { accumulation with SBW }\end{array}$ & $\begin{array}{l}\text { Analyze remaining tanks } \\
\text { for noble metals }\end{array}$ \\
\hline \multicolumn{3}{|c|}{ Off-gas characterization and treatment } \\
\hline $\begin{array}{l}\text { Solids scrubbing efficiency } \\
\text { in acid venturi scrubber }\end{array}$ & $\begin{array}{l}\text { ASPEN model completed but not } \\
\text { validated during pilot runs. }\end{array}$ & Deferred to FY-03 \\
\hline $\begin{array}{l}\text { Partitioning of acid gases } \\
\text { and Hg during } \\
\text { quench/scrubbing } \\
\text { operations }\end{array}$ & $\begin{array}{l}\text { Pilot test completed, but analysis remains } \\
\text { to confirm ASPEN model. Hg partitioning } \\
\text { only tested in laboratory with uncertain } \\
\text { results. }\end{array}$ & Deferred to FY-03 \\
\hline $\begin{array}{l}\text { Effects of other species on } \\
\text { Hg polishing effectiveness } \\
\text { of GAC }\end{array}$ & $\begin{array}{l}\mathrm{Hg} \text { partitioning evaluated in laboratory } \\
\text { tests with uncertain results. }\end{array}$ & Deferred to FY-03 \\
\hline $\begin{array}{l}\text { Will facility comply with } \\
\text { MACT }\end{array}$ & $\begin{array}{l}\text { Current baseline assumes MACT } \\
\text { compliance. }\end{array}$ & None \\
\hline
\end{tabular}




\begin{tabular}{lll}
\hline \multicolumn{1}{c}{ Design Basis Element } & \multicolumn{1}{c}{ Status - FY-01 } & Plans - DWP '02-'04 \\
\hline & Secondary Waste generation and disposal & \\
\hline GAC TCLP performance & $\begin{array}{l}\text { Calculations indicate } \mathrm{Hg}\left(\mathrm{as} \mathrm{HgCl}_{2}\right) \text { may } \\
\text { leach above TCLP. } \\
\text { "Demonstration of equivalency waiver" }\end{array}$ & Deferred to FY-04 \\
$\begin{array}{l}\text { Disposal requirements for } \\
\text { mercury-containing } \\
\text { secondary wastes }\end{array}$ & may be required for disposal. & NY-04 \\
$\begin{array}{l}\text { Should Sr-90 be extracted } \\
\text { from the scrubber } \\
\text { blowdown }\end{array}$ & $\begin{array}{l}\text { Baseline assumption assumes no removal } \\
\text { required. }\end{array}$ & None \\
\hline
\end{tabular}

Analysis of the above table reveals that the Priority 1 elements have increased during the past year, largely attributable to discoveries associated with sulfate and mercury. Resolution of these key issues is required before a process flowsheet can be finalized. Also note that a number of the priority 1 elements have been deferred beyond CD-0 (Approve Mission Need). Although this may be acceptable for obtaining CD-0 approval in FY-03, continued focus will be required to ensure these elements are addressed prior to Title 1 design in FY-05 (CD-1 - Approve Preliminary Baseline Range). Of the 17 Priority 1 DBEs identified above, 135 lower-priority DBEs are also contained in the technical baseline database. Each of these will go through the risk screening and mitigation process outlined in the RMP. Some of these will be accepted as is, but the majority will require some type of action to resolve.

Appendix A shows the detailed EM-40 or -50 funded activities contained in the DWP for FY-02 through FY-04. (Note: EM-50 tasks are only shown through FY-02.) Of particular concern is the limited number of bench and pilot plant studies planned before CD-0. To date, these studies, conducted at Clemson University and Pacific Northwest National Laboratory, have been instrumental in identifying potential issues. With only bench-scale testing currently scoped in FY-02, the potential for scale-up issues remains. Although these uncertainties are thought to be solvable through additional testing, resolution prior to CD-0 may not be supported. In the interim, the Project is typically forced to make conservative assumptions relative to equipment and process needs that tend to increase project cost estimates.

Although not clear from the schedule, the tasks associated with HM125, Pilot Melter Procurement and Testing, are for a cold-crucible induction melter (CCIM), not the baseline joule-heated melter. Increasing the INEEL (and DOE complex) knowledge base of this melter technology was deemed important relative to alternative analysis in preparation for CD-0. Furthermore, due to potential scale-up issues identified, deployment of a larger scale joule-heated melter either to the INEEL or in support of the INEEL is planned, but will not be on line for several years (about 2012).

As shown by Figure 1, the funding profile for technology development work is shown to increase throughout the DWP planning horizon. Not shown is the funding reduction in FY-01 from $\$ 8.2 \mathrm{M}$ to $\$ 6.4 \mathrm{M}$. This reduction has been compensated by increased funding in FY-02 relative to last year's roadmap estimate of $\$ 2.8 \mathrm{M}$. However, with the discoveries that occurred in FY-01, finalizing the process flowsheet prior to CD-0 remains uncertain. It is anticipated that the increased funding in FY-03/04, provided it is retained, will be essential to resolve key issues such as sulfate layer accumulation, scale-up issues, and mercury speciation prior to CD-1, which is estimated to occur in FY-05. 


\section{SBW Technology Development Projected Funding Profile}

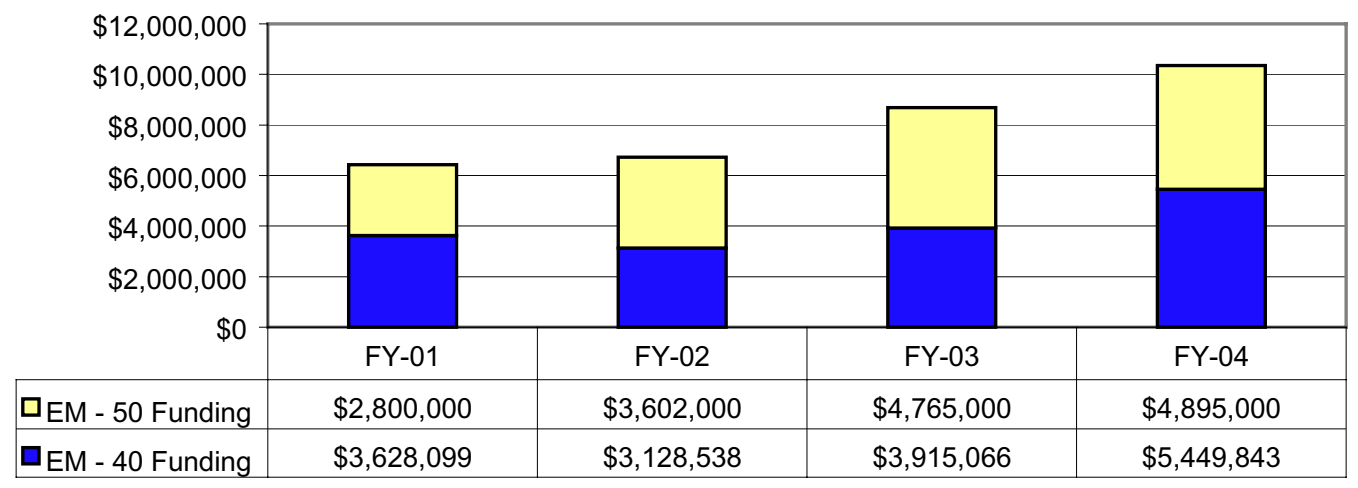

Figure 1. SBW Technology Development Projected Funding Profile.

Appendix B provides the planning schedule for the SBW Vitrification Project. The schedule illustrates, at a high-level, the technology development tasks funded by EM-40 to support the critical decision points in the Project. As mentioned above, currently scoped activities will not allow verification of the process flowsheets until CD-1. The Risk Assessment Reports, not shown specifically on the schedule, but included under the Pre-conceptual Project Management activity, will be completed prior to CD-0. This document will reflect the status of the technical uncertainties for the Project at that point in time. The various CD review teams and officials will then assess the viability to proceed based upon the perceived risks and mitigation plans. Also note that the schedule does not identify significant technology development activities in support of the project during the construction phase and beyond. Additional operating funds will be sought during these phases to ensure pilot plant operation can be used to support the project and subsequent operations. 


\section{TRANSITION TO RISK MANAGEMENT PLAN}

A primary function of roadmapping is identification and management of technical risk. Likewise, the Risk Management Plan (RMP), although broader in scope, has the same function. The four major phases of roadmapping - (1) initiation, (2) needs assessment, (3) response development, and (4) implementation - are effectively addressed by the RMP. This is illustrated by comparing Figure 2, Roadmapping Process and Products Diagram, (EM S\&T Roadmappping 2000) with Figure 3, Work Breakdown Structure for the RMP (Bryan 2001). 


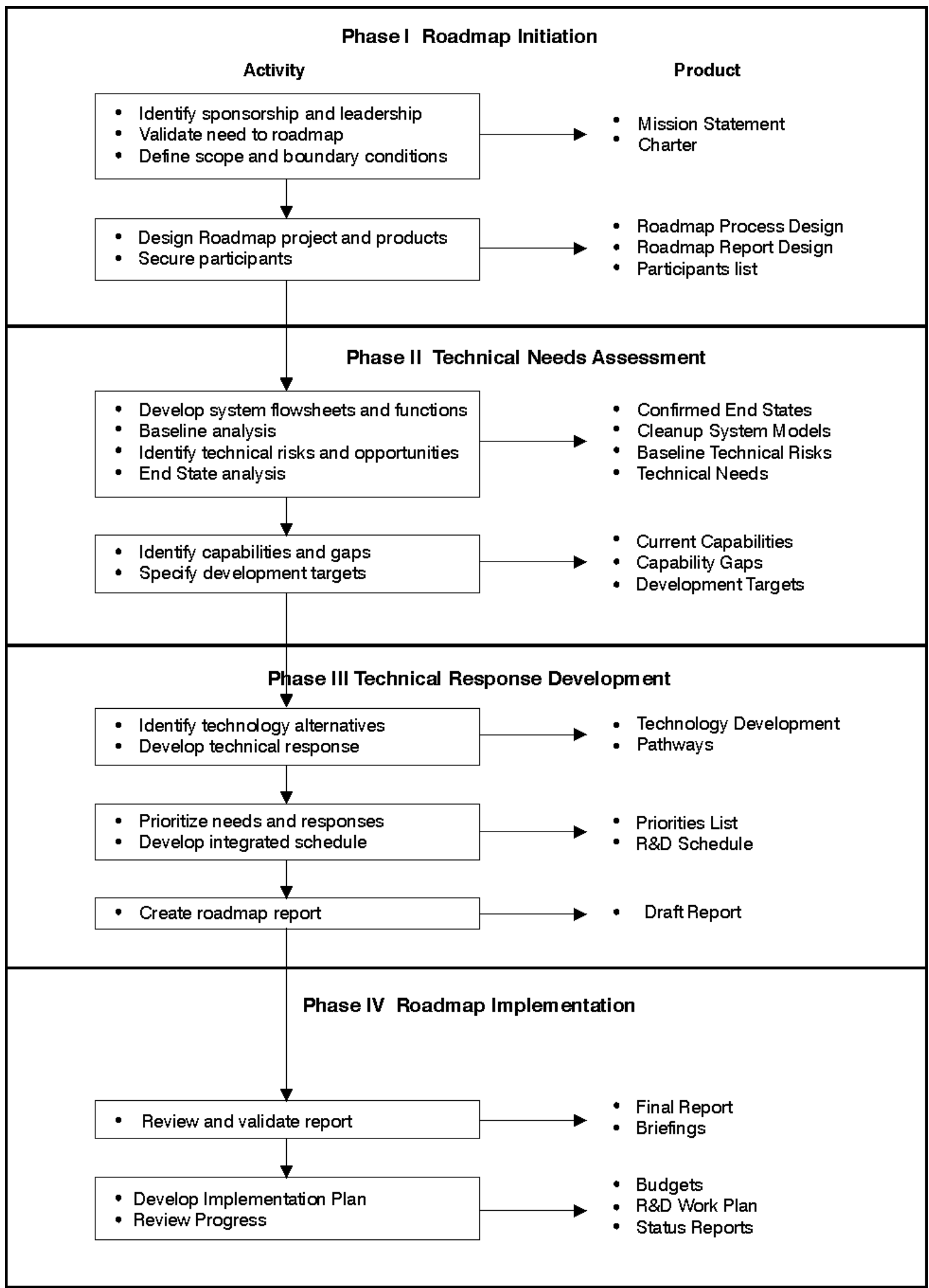

01-GA51 025-01

Figure 2. Roadmapping Process and Products Diagram (as provided in the EM-50 Draft Guidance). 


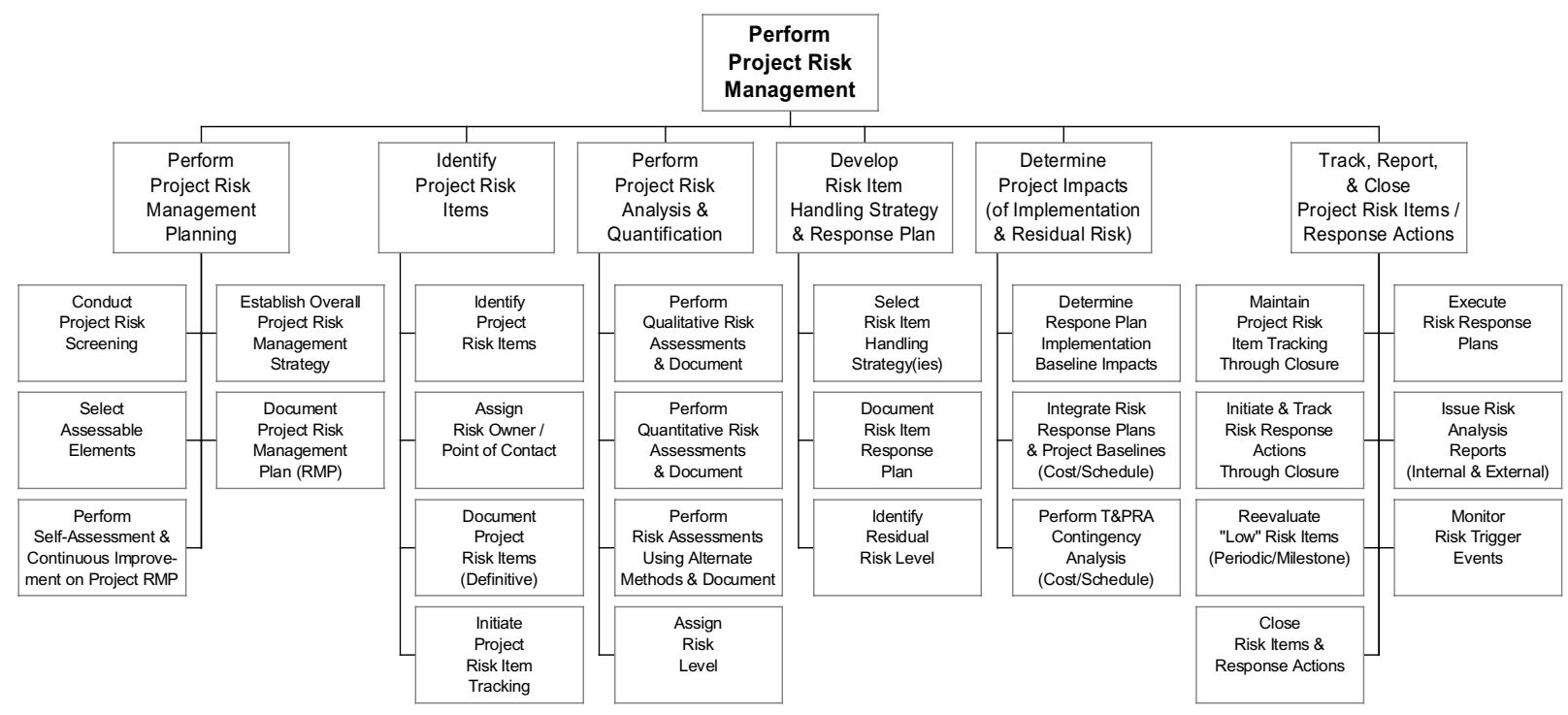

Figure 3. Risk Management Plan WBS.

It is clear from comparison of these two figures that following the outline of the RMP will ensure the intent of roadmapping is upheld.

To further illustrate this, it is important to understand how the RMP plan fits into the overall framework of the Construction Project. Figure 4 and 5 below illustrates how the RMP and associated documents will be addressed during each critical decision stage of the Project (Bryan 2001). The Project is currently in the pre-conceptual phase with CD-0 planned in FY-03.

\begin{tabular}{|l||l|l|l|l|l|}
\hline \multirow{2}{*}{$\begin{array}{l}\text { Risk Management } \\
\text { Documentation }\end{array}$} & $\begin{array}{c}\text { Pre-Conceptual } \\
\text { (CD-0) }\end{array}$ & $\begin{array}{c}\text { Conceptual } \\
\text { Design (CD-1) }\end{array}$ & $\begin{array}{c}\text { Preliminary } \\
\text { Design (CD-2) }\end{array}$ & $\begin{array}{c}\text { Final Design } \\
\text { (CD-3) }\end{array}$ & \multicolumn{1}{|c|}{$\begin{array}{c}\text { As-Built } \\
\text { (CD-4) }\end{array}$} \\
\hline \hline $\begin{array}{l}\text { Risk Management } \\
\text { Plan }\end{array}$ & Issued & $\begin{array}{l}\text { Issued (updated } \\
\text { if necessary) }\end{array}$ & $\begin{array}{l}\text { Issued (updated } \\
\text { if necessary) }\end{array}$ & $\begin{array}{l}\text { Issued (updated } \\
\text { if necessary) }\end{array}$ & $\begin{array}{l}\text { Issued (updated } \\
\text { if necessary) }\end{array}$ \\
\hline $\begin{array}{l}\text { Risk Screening } \\
\text { Checklist }\end{array}$ & Complete & NA & NA & NA & NA \\
\hline Risk Item Log & $\begin{array}{l}\text { Established; } \\
\text { populated with } \\
\text { identified risks }\end{array}$ & $\begin{array}{l}\text { Established; } \\
\text { populated with } \\
\text { identified risks }\end{array}$ & $\begin{array}{l}\text { Established; } \\
\text { populated with } \\
\text { identified risks }\end{array}$ & $\begin{array}{l}\text { Established; } \\
\text { populated with } \\
\text { identified risks }\end{array}$ & $\begin{array}{l}\text { Established; } \\
\text { populated with } \\
\text { identified risks }\end{array}$ \\
\hline
\end{tabular}




\begin{tabular}{|c|c|c|c|c|c|}
\hline \multirow[b]{2}{*}{$\begin{array}{l}\text { Risk Management } \\
\text { Documentation }\end{array}$} & \multicolumn{5}{|c|}{ Project-Specific Expectations for End of Project Phase } \\
\hline & $\begin{array}{c}\text { Pre-Conceptual } \\
\text { (CD-0) }\end{array}$ & $\begin{array}{c}\text { Conceptual } \\
\text { Design (CD-1) }\end{array}$ & $\begin{array}{c}\text { Preliminary } \\
\text { Design (CD-2) }\end{array}$ & $\begin{array}{c}\text { Final Design } \\
\text { (CD-3) }\end{array}$ & $\begin{array}{l}\text { As-Built } \\
\text { (CD-4) }\end{array}$ \\
\hline $\begin{array}{l}\text { Risk Identification } \\
\text { and Response Plan } \\
\text { Forms }\end{array}$ & $\begin{array}{l}\text { Complete for } \\
\text { identified risks; } \\
\text { quantified with } \\
\text { conceptual } \\
\text { response plan } \\
\text { (i.e., mitigation } \\
\text { strategy) } \\
\text { defined; rough } \\
\text { order of } \\
\text { magnitude cost } \\
\text { \& schedule } \\
\text { impacts } \\
\text { (implementation } \\
\text { \& residual risk) } \\
\text { identified }\end{array}$ & $\begin{array}{l}\text { Complete and } \\
\text { updated for } \\
\text { identified risks; } \\
\text { quantified with } \\
\text { preliminary } \\
\text { response plan } \\
\text { (i.e., mitigation } \\
\text { strategy) } \\
\text { defined and } \\
\text { integrated into } \\
\text { project } \\
\text { schedule; } \\
\text { preliminary cost } \\
\text { \& schedule } \\
\text { impacts } \\
\text { (implementation } \\
\text { \& residual risk) } \\
\text { estimated }\end{array}$ & $\begin{array}{l}\text { Complete and } \\
\text { updated for } \\
\text { identified risks; } \\
\text { quantified with } \\
\text { detailed } \\
\text { response plan } \\
\text { (i.e., mitigation } \\
\text { strategy) } \\
\text { defined and } \\
\text { integrated into } \\
\text { project } \\
\text { schedule; } \\
\text { detailed cost \& } \\
\text { schedule } \\
\text { impacts } \\
\text { (implementation } \\
\text { \& residual risk) } \\
\text { estimated }\end{array}$ & $\begin{array}{l}\text { Complete and } \\
\text { updated for } \\
\text { identified risks; } \\
\text { quantified with } \\
\text { detailed } \\
\text { response plan } \\
\text { (i.e., mitigation } \\
\text { strategy) } \\
\text { defined and } \\
\text { integrated into } \\
\text { project } \\
\text { schedule; } \\
\text { detailed cost \& } \\
\text { schedule } \\
\text { impacts } \\
\text { (implementation } \\
\text { \& residual risk) } \\
\text { estimated }\end{array}$ & $\begin{array}{l}\text { Complete and } \\
\text { updated for } \\
\text { identified risks; } \\
\text { quantified with } \\
\text { detailed } \\
\text { response plan } \\
\text { (i.e., mitigation } \\
\text { strategy) } \\
\text { defined and } \\
\text { integrated into } \\
\text { project } \\
\text { schedule; } \\
\text { detailed cost \& } \\
\text { schedule } \\
\text { impacts } \\
\text { (implementation } \\
\text { \& residual risk) } \\
\text { estimated }\end{array}$ \\
\hline $\begin{array}{l}\text { Risk Response } \\
\text { Plan Action } \\
\text { Tracking System }\end{array}$ & Concept defined & $\begin{array}{l}\text { Established and } \\
\text { populated with } \\
\text { response plan } \\
\text { actions }\end{array}$ & $\begin{array}{l}\text { Established and } \\
\text { populated with } \\
\text { response plan } \\
\text { actions } \\
\text { (updated) }\end{array}$ & $\begin{array}{l}\text { Established and } \\
\text { populated with } \\
\text { response plan } \\
\text { actions } \\
\text { (updated) }\end{array}$ & $\begin{array}{l}\text { Established and } \\
\text { populated with } \\
\text { response plan } \\
\text { actions } \\
\text { (updated) }\end{array}$ \\
\hline $\begin{array}{l}\text { Risk Assessment } \\
\text { Reports (RARs) }\end{array}$ & $\begin{array}{l}\text { Conceptual } \\
\text { RAR complete - } \\
\text { risks address } \\
\text { high-level } \\
\text { functions \& } \\
\text { requirements, } \\
\text { programmatic/ } \\
\text { cost/schedule } \\
\text { issues. ROM } \\
\text { T\&PRA } \\
\text { contingency } \\
\text { calculated and } \\
\text { added into } \\
\text { project cost } \\
\text { estimate. }\end{array}$ & $\begin{array}{l}\text { Preliminary RAR } \\
\text { complete - risks } \\
\text { include previous } \\
\text { risks (updated) } \\
\text { plus new } \\
\text { programmatic, } \\
\text { cost, and } \\
\text { schedule risks } \\
\text { and technical } \\
\text { risks to the } \\
\text { facility (i.e., } \\
\text { subproject) } \\
\text { level. T\&PRA } \\
\text { contingency } \\
\text { calculated and } \\
\text { added into } \\
\text { project cost } \\
\text { estimate. }\end{array}$ & $\begin{array}{l}\text { RAR complete - } \\
\text { risks include } \\
\text { previous risks } \\
\text { (updated) plus } \\
\text { new } \\
\text { programmatic, } \\
\text { cost, and } \\
\text { schedule risks } \\
\text { and technical } \\
\text { risks to the } \\
\text { system level. } \\
\text { T\&PRA } \\
\text { contingency } \\
\text { calculated and } \\
\text { added into } \\
\text { project cost } \\
\text { estimate. }\end{array}$ & $\begin{array}{l}\text { RAR complete - } \\
\text { risks include } \\
\text { previous risks } \\
\text { (updated) plus } \\
\text { new } \\
\text { programmatic, } \\
\text { cost, and } \\
\text { schedule risks } \\
\text { and technical } \\
\text { risks to the } \\
\text { component } \\
\text { level. T\&PRA } \\
\text { contingency } \\
\text { calculated and } \\
\text { added into } \\
\text { project cost } \\
\text { estimate. }\end{array}$ & $\begin{array}{l}\text { RAR complete - } \\
\text { risks include } \\
\text { previous risks } \\
\text { (updated) plus } \\
\text { new } \\
\text { programmatic, } \\
\text { cost, and } \\
\text { schedule risks } \\
\text { and all identified } \\
\text { technical risks. } \\
\text { T\&PRA } \\
\text { contingency } \\
\text { calculated and } \\
\text { added into } \\
\text { project cost } \\
\text { estimate. }\end{array}$ \\
\hline
\end{tabular}

Figure 4. Risk Management Plan Documents Relative to Project Phase. 
Figure 5. Risk Management Process Relative to Project Phase.

The charts above illustrate how the technical (as well as programmatic) risks of the Project will be addressed as the Project progresses through each critical decision point.

Pertinent to the technical risks will be generation of the Risk Assessment Reports just prior to CD-0. At CD-0, while it is known that technical risks will remain unresolved, the key to approval is identifying and developing mitigation plans for resolution.

A companion document to this roadmap update is the INEEL SBW Vitrification Process (Taylor, Barnes, and Lauerhass 2001). This key document provides the baseline flowsheet for SBW treatment. Furthermore, it contains a listing of the DBEs contained in the technical baseline database and therefore, these are not repeated in this document. Consistent with the roadmap, a transition to managing technical risks under the RMP is supported. 


\section{CONCLUSIONS}

Based on analysis of the progress made in technology development and the progression toward design of a facility for processing SBW, the following conclusions relative to roadmapping are drawn:

- $\quad$ Considerable progress is being made in characterizing waste and resultant glass.

- Melter bench and pilot testing have effectively utilized expertise available. These tests and related studies have been effective at establishing a baseline flowsheet.

- $\quad$ Discoveries such as formation of a sulfate layer in the melt are forcing reduction in anticipated waste loadings and/or waste formulation changes.

- $\quad$ Further pilot testing to address identified issues remains paramount.

- Transition from the roadmap to the Risk Management Plan should ensure technical risks continue to be identified, tracked and resolved.

- $\quad$ Progressing to CD-0 with current uncertainties requires continued focus.

- $\quad$ Task identification prior to CD-1 currently appears adequate provided (1) identified funding is retained, and (2) additional discoveries are not uncovered during subsequent testing.

- Utilization of pilot melters across the complex is noteworthy. However, scale-up issues remain. Larger scale melters exist in the complex and redeployment either to INEEL or in support of INEEL should be pursued to address the unique SBW waste type.

- The potential advantages of cold-crucible induction melter technology warrant continued focus. 


\section{REFERENCES}

Bryan, Jeffrey D, September 6, 2001, "Risk Management Plan for the Idaho Waste Vitrification Facilities Project," PLN-909.

DOE Order 413.3, October 13, 2000, "Program and Project Management for the Acquisition of Capital Assets," U.S. Department of Energy.

EM-PDRI, February 2001, "Office of Environmental Management Project Definition Rating Index (EMPDRI) Manual,” U.S. Department of Energy, Office of Environmental Management.

EM-S\&T Roadmapping, Draft B, 2000, “Applying Science and Technology Roadmapping in Environmental Management," U.S. Department of Energy, Office of Environmental Management.

Olson, Arlin, James Murphy, and Keith Perry, September 28, 2000, Pre-Decisional Sodium Bearing Waste Technology Development Roadmap, INEEL/EXT-2000-01299.

Taylor, Dean, Charles Barnes, and Lance Lauerhass, September 2001, INEEL SBW Vitrification Process, INEEL/EXT-01-01139. 


\section{Appendix A \\ Bechtel BWXT Idaho, LLC \\ PBS-102 Idaho Waste Vitrification Technology Development Work Package Schedules}




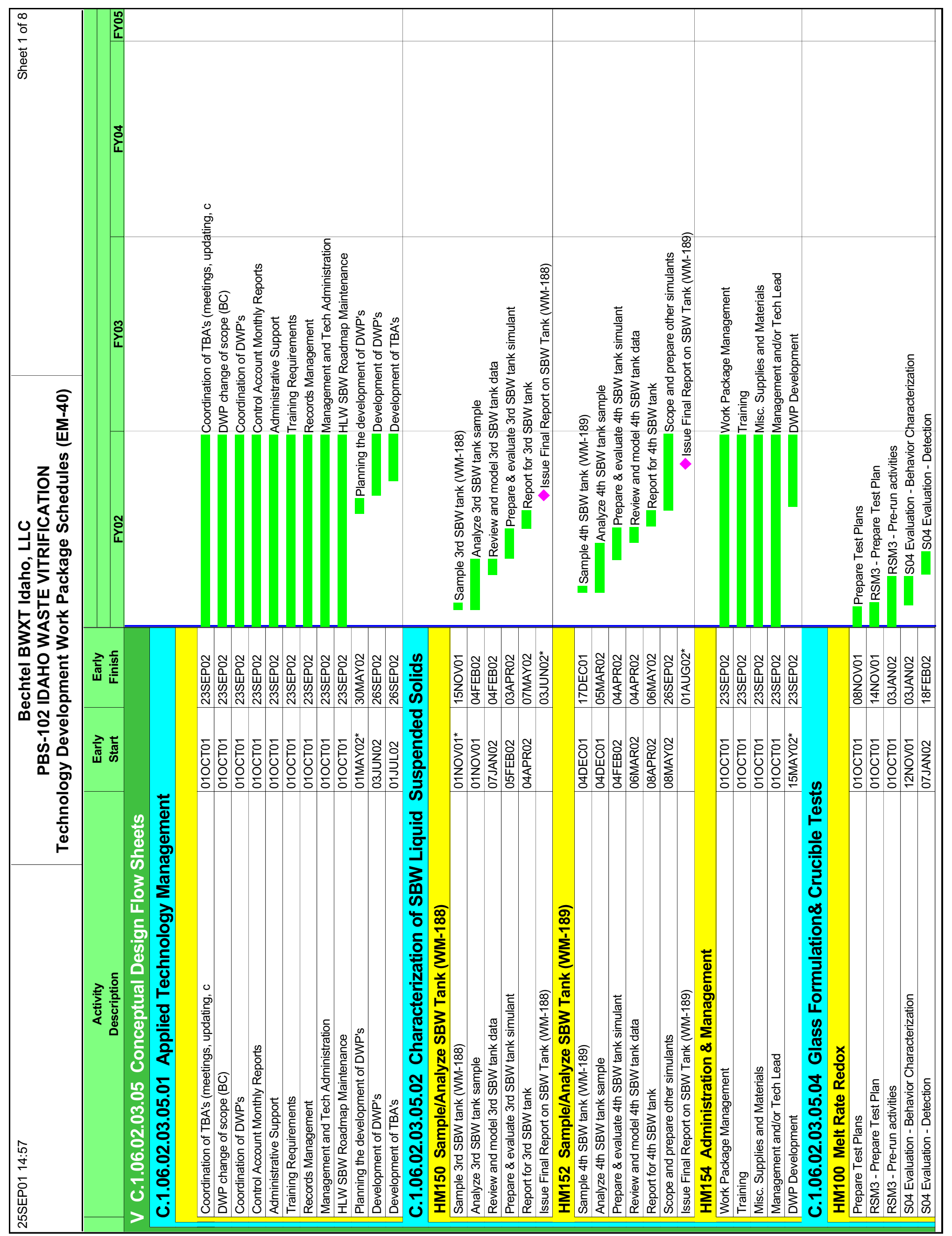




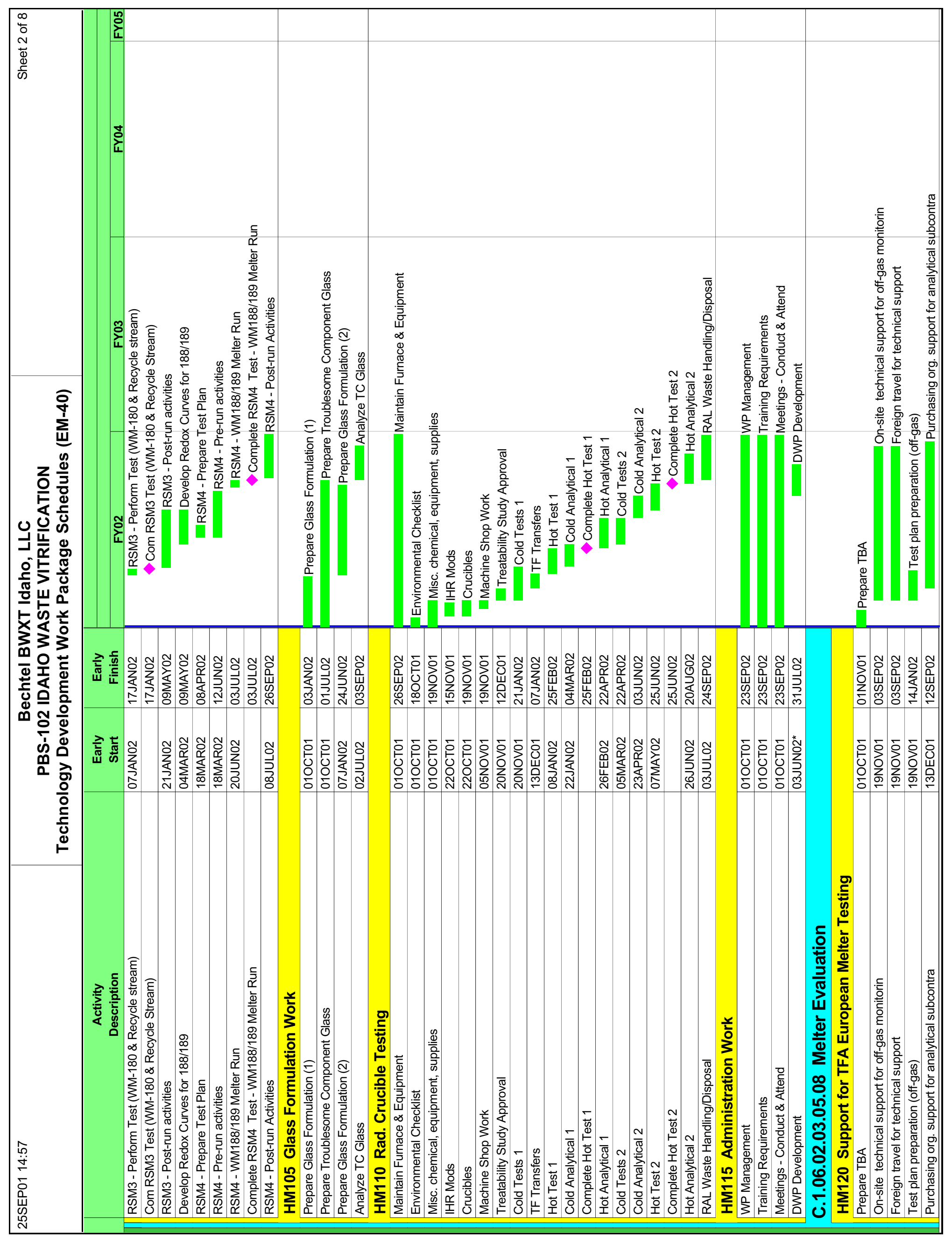




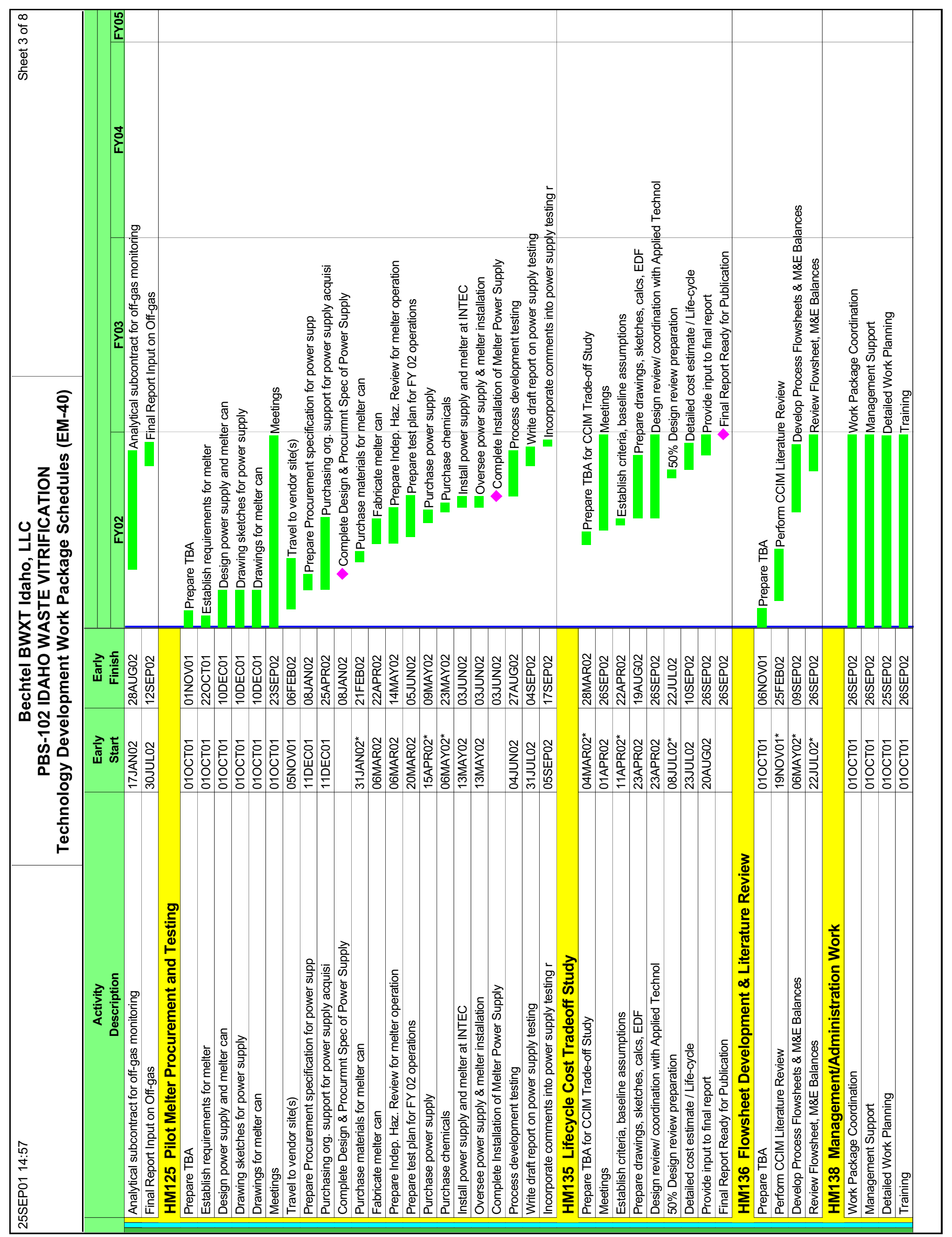




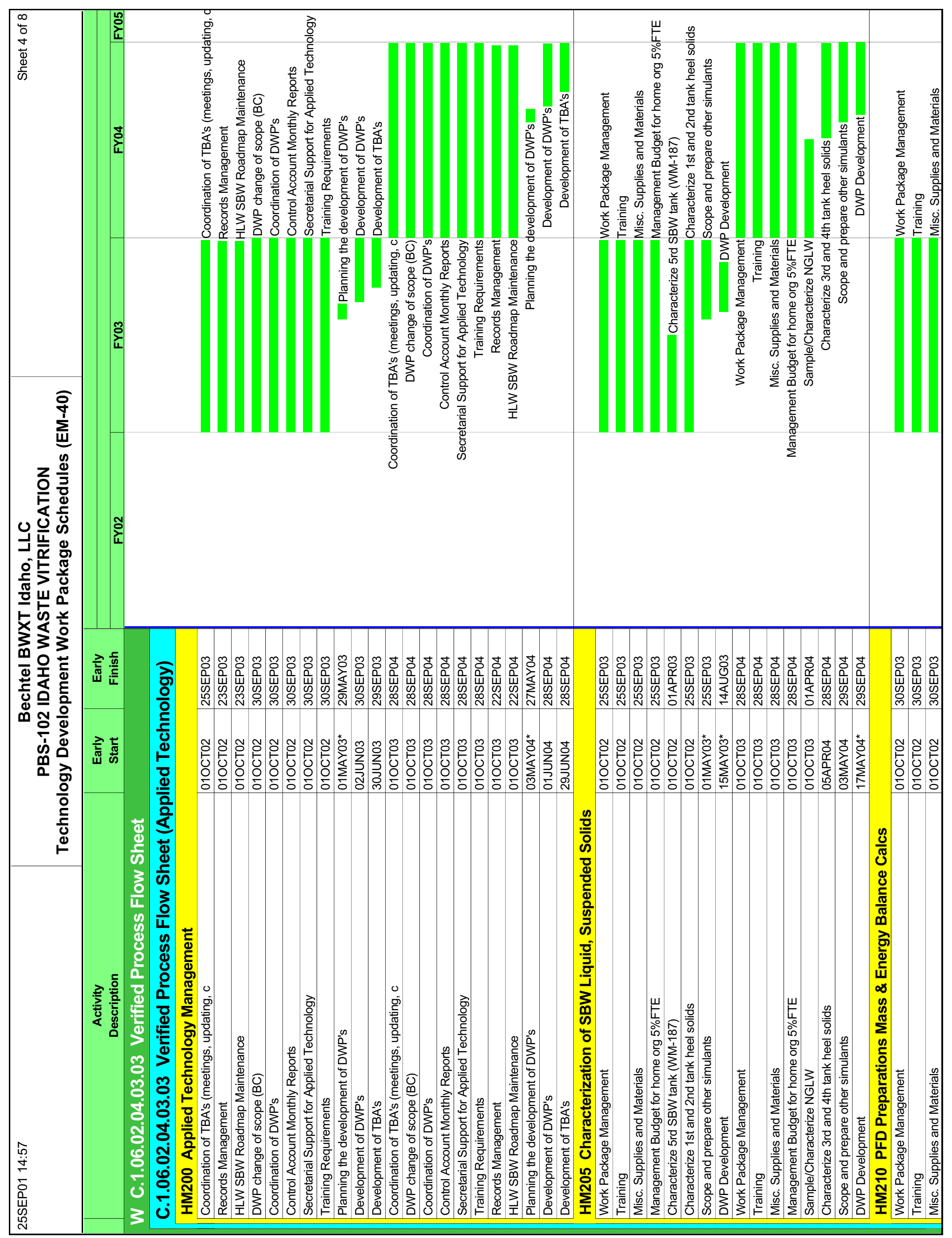




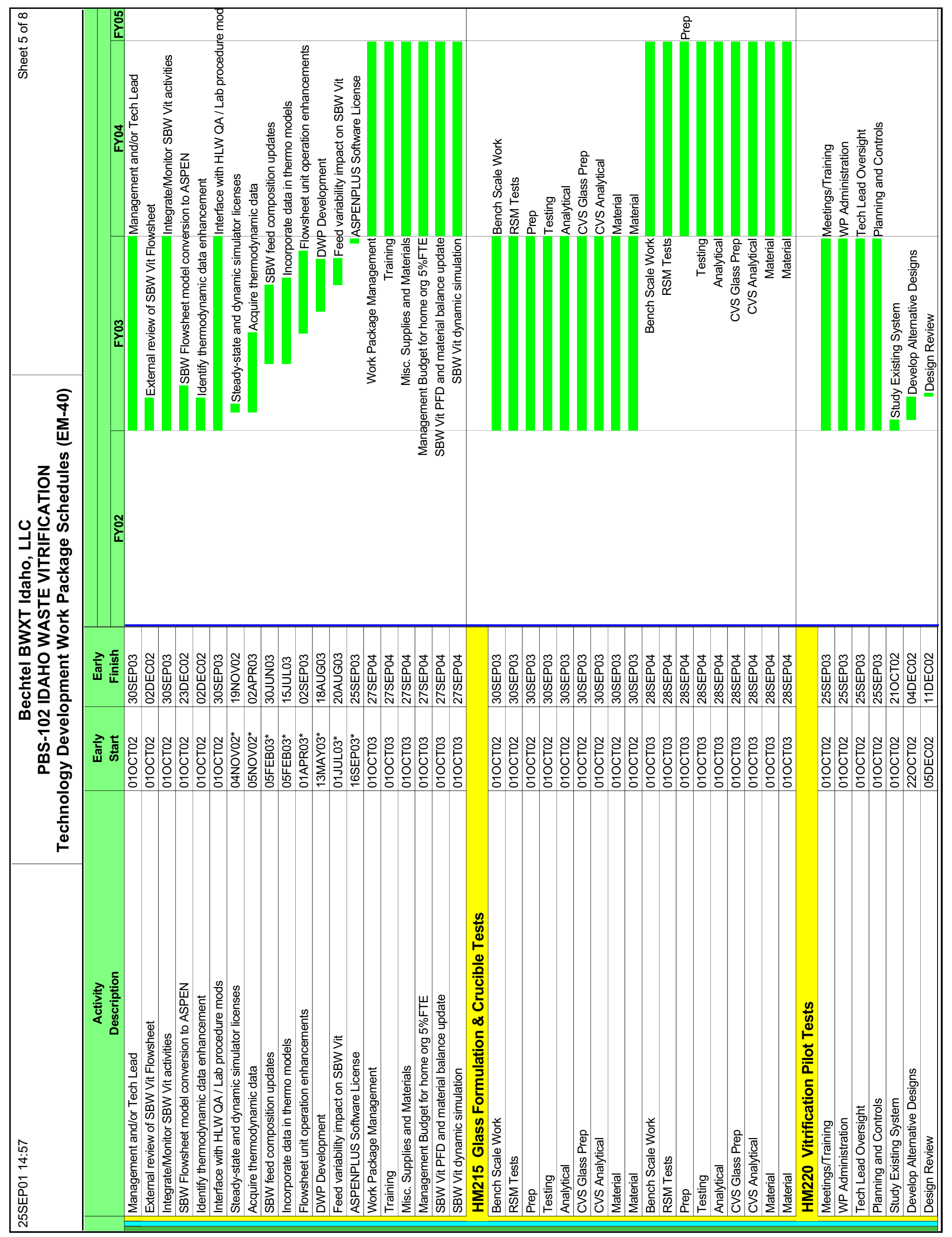




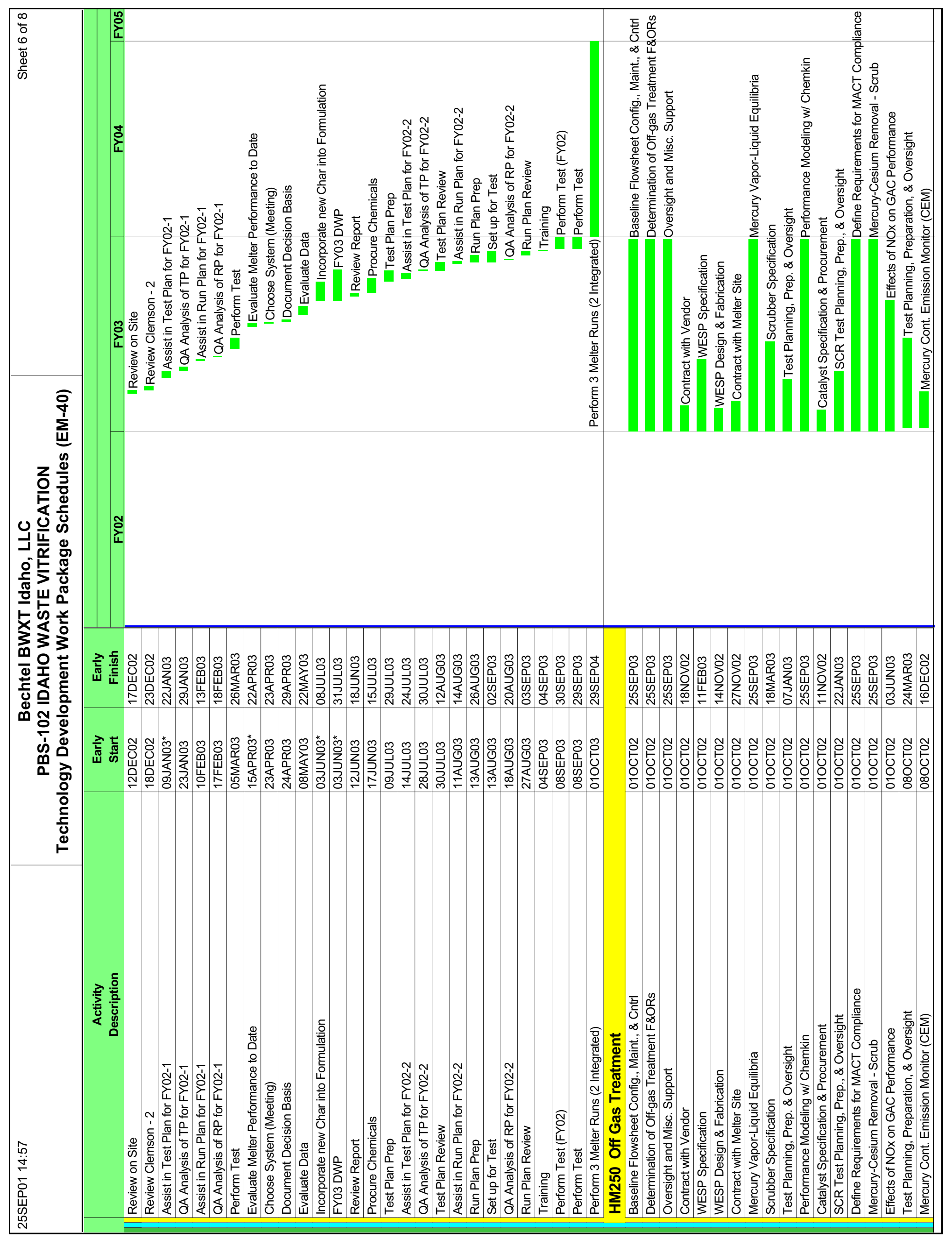




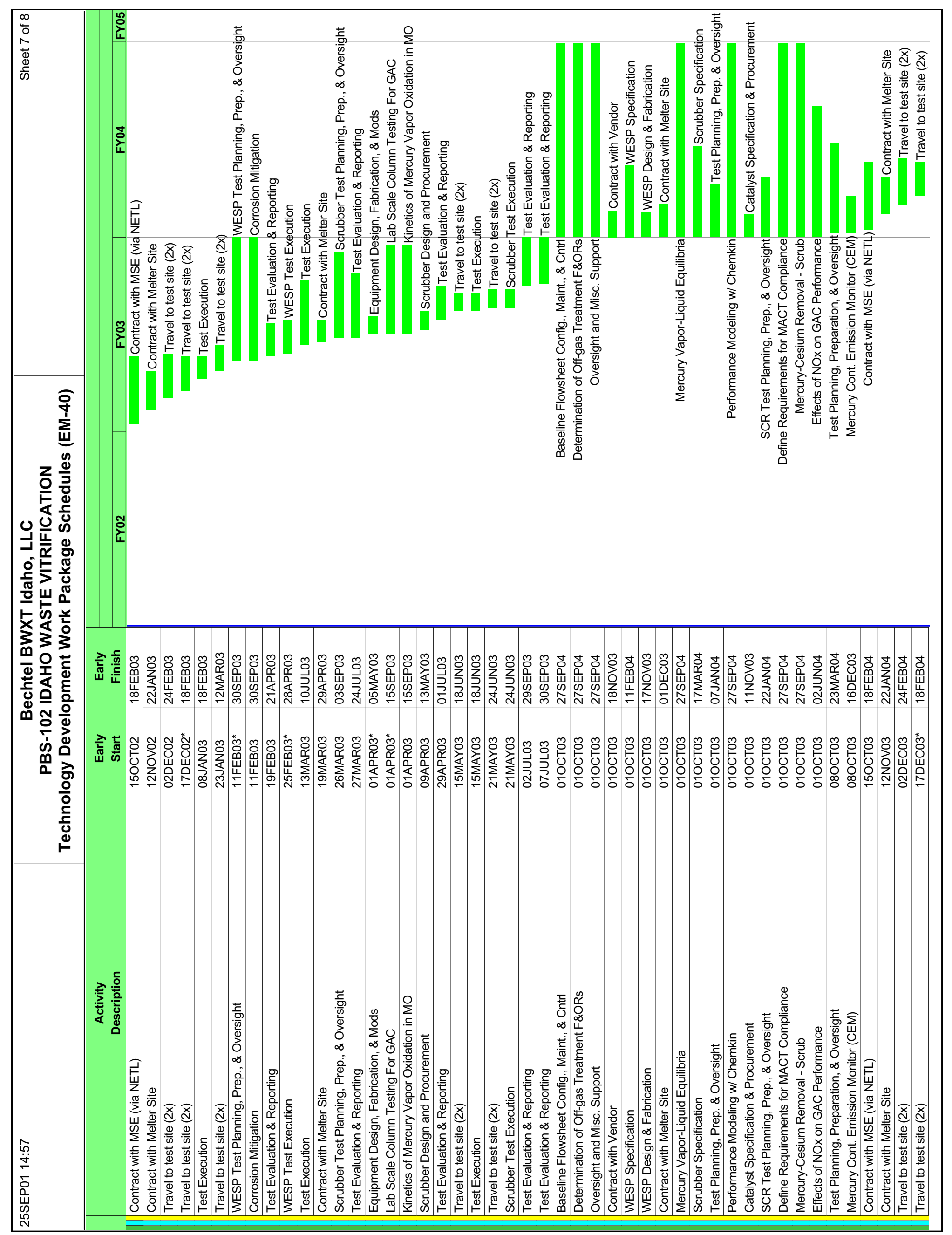




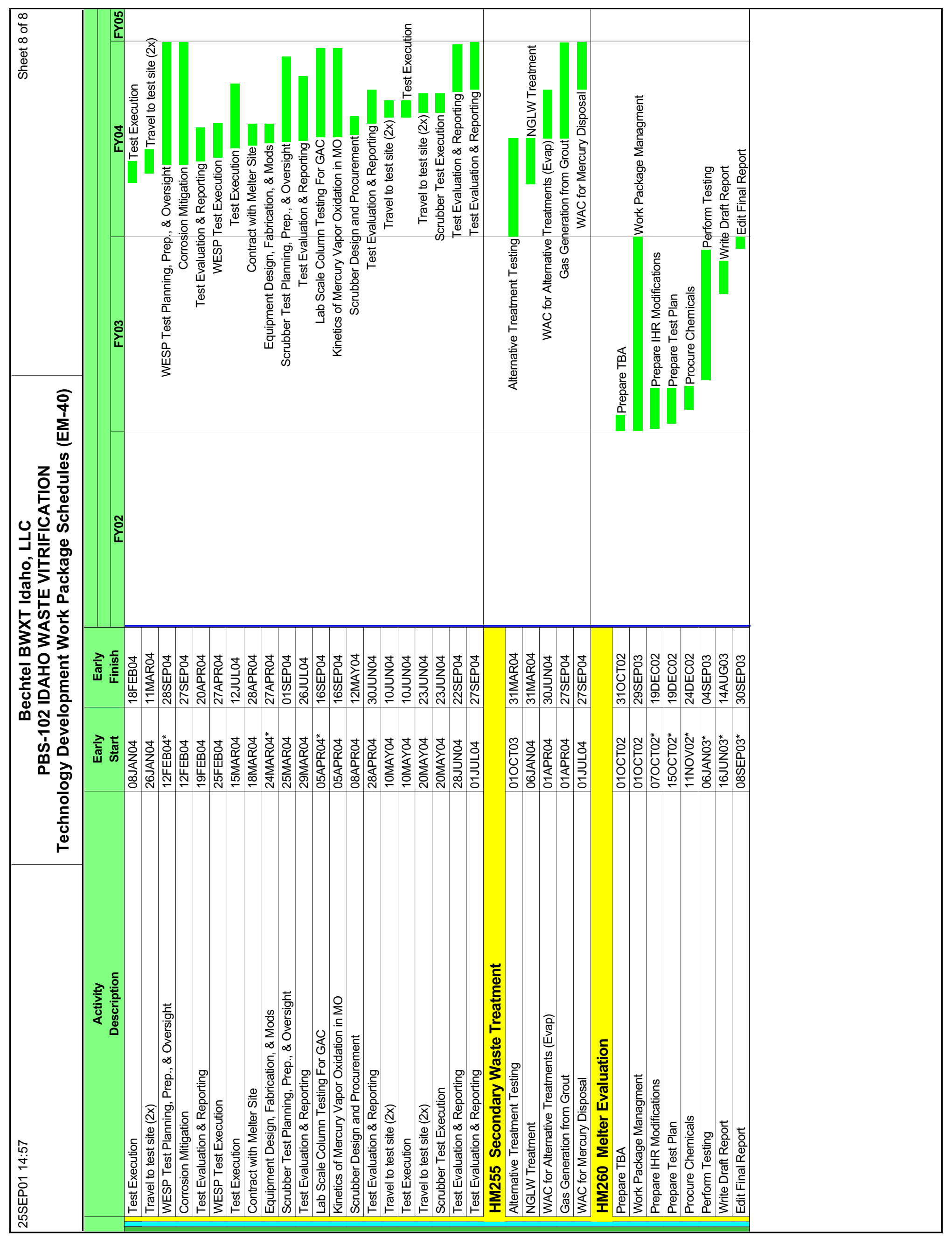




\section{Appendix B}

\section{Idaho Waste Vitrification Facilities Project Schedule}




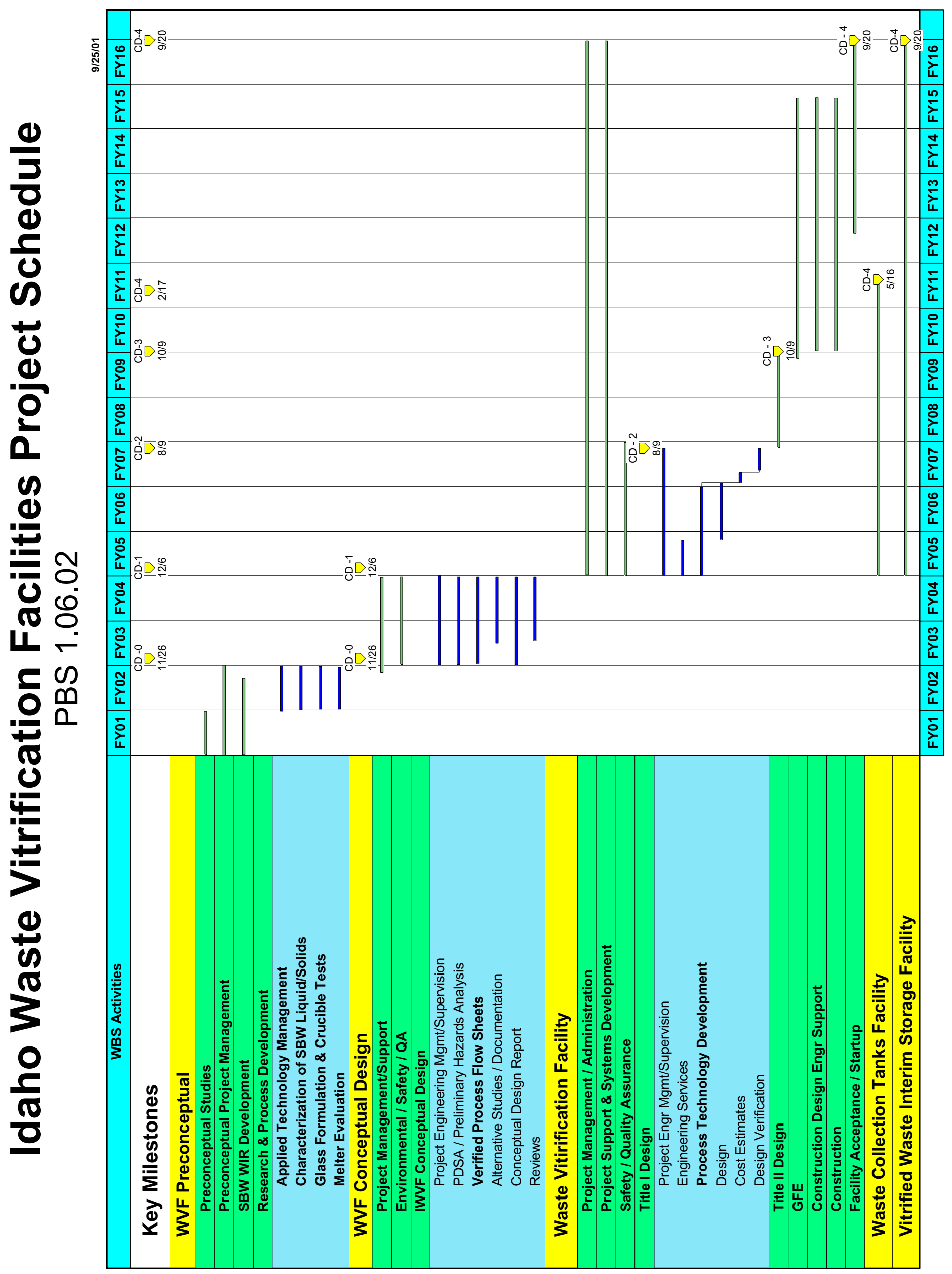

